\title{
Protestant Minorities in European States and Nations
}

\author{
Joseph Ruane and Jennifer Todd \\ University College Cork University College Dublin
}

3956 ww excluding abstract

Contact: joseph.ruane@ucc.ie 


\title{
Protestant Minorities in European States and Nations
}

\begin{abstract}
Little attention has been paid in the recent scholarly literature to Europe's old religious conflicts, in particular those that stem from the reformation. Yet for long religiously informed conflict was the principal source of internal state division and the major perceived threat to state stability and security. This paper looks at the institutional changes and cultural renegotiations which allowed traditional religious oppositions, rivalries and conflicts to fade in most contemporary European societies. Focussing on the Czech, French and Irish cases, it argues that neither modernisation, democratisation nor secularisation were enough to resolve deep-set tensions. The long-term resolutions involved a restructuring of polity and nation in a way consistent with minority as well as majority culture. In the past - and perhaps also in the present - such opportunities were rare and demanded choice, strategy and political fortune.
\end{abstract}

Keywords: religious conflicts, reformation divisions, states, democratisation, minority-majority relations. 


\section{Protestant Minorities in European States and Nations ${ }^{1}$}

\section{By Joseph Ruane and Jennifer Todd}

Europe's traditional ethnic minorities and the conflicts over their place in the state and nation are the focus of continuing comparative research (Laitin, 1998; Coakley, 2003; Brubaker, 2004, 2007; Kaufmann, 2004; Keating, 2001; Wimmer, 2008). A growing literature deals with the political tensions surrounding Europe's new religious minorities, in particular Islam (Bail, 2008, 44; Fetzer and Soper, 2005). In contrast, little attention is paid to Europe's older religious conflicts, in particular those that stem from the reformation. The exception is of course Northern Ireland, and this is most often studied as an ethnic conflict, with its religious aspects left aside. ${ }^{2}$ Yet for long religiously informed conflict was the principal source of internal state division and the major perceived threat to state stability and security. Rather like ethnicity, religious opposition had a totalising quality, involving close-knit communities with oppositional cultures and values and different ways of life, embedded in institutions, and linked to wider geo-political struggles over national boundaries and state power. For the two centuries that followed the reformation, states everywhere sought religious homogeneity and marginalized and persecuted their religious minorities. In

the $19^{\text {th }}$ century the emphasis was on emancipation and integration, but religious identities remained strong and older conflicts frequently emerged in new guise. Where the minority was small, conflict could be contained; where it was large or a majority in a particular region it could intensify confessional competition, challenge the form of the state and call into question its boundaries (Rokkan and Urwin, 1983; Flora, 1999; Marx, 2003; Liedke and Wendenhorst, 1999; Colley, 1992 ; Hastings, 1997; Mews, 1982; Smith 1995; Gross 2005). 
Today - again with the exception of Northern Ireland - traditional religious oppositions, rivalries and conflicts have faded and religious identities have lost much of their intensity. How did this come about? The most common explanation is modernisation, defined in terms of political liberalism, religious pluralism, individualism, secularism and (latterly) consumerism. These have moderated division and even removed their basis in religious belief. But modernisation is too general an explanation and raises other questions. ${ }^{3}$ If, as we know, modernisation can intensify the sense of ethnic distinction, why did it moderate the religious one? And how exactly did modernisation work? Did it weaken the intensity of religious conviction, or did it simply make religious divisions less politically salient? Insofar as it was the latter, was this simply by widening citizenship and universalising rights, or by interventions that unlocked the historically specific relations of antagonism between majority and minority? Finally, was the process fundamentally different where religion was correlated with ethnicity, or with different conceptions of the nation? These questions relate to the past but they are relevant to the present. On the one hand, they point to successful methods of accommodation of minorities. On the other, they draw attention to the complexities and pitfalls of the process, and give us a critical stance on what it may take to resolve contemporary conflicts. There is a further issue: as religion again becomes an important political issue in Europe, we should not rule out the possibility that Europe's new religious divisions will intersect with what remains of its old ones (Jenkins, 2007). There is much to learn from revisiting these older religious tensions and the manner and extent of their resolution.

Our particular concern is with Protestant minorities in majority-Catholic countries. John Coakley's survey puts this group into historical context. Contemporary Europe's 
geo-religious foundations were set in the crucial two centuries of the wars of religion. The identities, affiliations and institutions that crystallised then remained remarkably stable in the centuries that followed, until industrialisation, urbanisation and changing state boundaries changed the territorial mix. Broadening the work of Stein Rokkan and including central Europe, Coakley identifies three zones: (i) the Lutheran North where the victory of the reformation was most complete and Catholicism disappeared entirely: the five Nordic countries with pre-1870 Prussia and post-1918 Estonia; (ii) a mixed zone including the United Kingdom, Holland, Switzerland and extending over much of Germany, typically consisting of a Protestant majority and a substantial Catholic minority, but on occasion the reverse, as in Slovakia and Hungary; (iii) a third overwhelmingly Catholic zone represented by France, Belgium, Austria, Italy, Spain and Portugal, with tiny Protestant minorities. We might also see this as a Protestant north European core surrounded on three sides (west, south, east) by Catholic counter-reformation countries stretching from Ireland in the north-west to Poland in the north-east, with a mixed interface region between them.

This religious inheritance remains part of Europe's fabric today, still a palpable presence in its state and political traditions, educational institutions, public architecture, art and literature, laws, cultural presuppositions, historical narratives, social memories, public rituals and symbols and, to some degree still, the habitus of its peoples. On the other hand institutional differentiation and the politics of secularism have now largely confined the expression of religious belief and values to the private sphere, and religious belief, participation in religious ceremonies and the religious education of the young are in sharp decline. Secularisation is more advanced in the Protestant countries than in the Catholics ones and, as Coakley points out, if 
one excludes those who are non-practicing, non-believing or who otherwise declare themselves to be unaffiliated to a Protestant church, Protestants are now a minority in every country in Europe.

Despite what appears as an inexorable decline, there is also evidence of persistence and certainly of a reluctance entirely to let go. In the Protestant North where Lutheran churches are still established and where there is a financial incentive to resign from the church, relatively few do so. In France, which records the highest levels of disaffiliation and the greatest distantiation of church and state, secular as much as religious Protestants remain attached to their heritage (Baubérot 1988). In the Czech Republic advanced secularism at the institutional level coexists with a much stronger personal religiosity (Lužný and Václavík, 2007). There is also 'vicarious religion' where those who do not believe or practice themselves want others to continue to do so, and want religion to remain part of their society (Davie, 2002). Its resilience should not be underestimated. It has a solid foundation in an exchange in which nonbelievers provide believers with moral (and in various ways financial) support and believers provide the non-believers with their comforting presence. There may also be movement between these categories: those who are in the 'vicarious' group at one stage in the lives may move into the believing (or partially believing) group at a later stage, or vice versa. From this perspective, the traditional religious distinctions retain a potential force.

The articles which follow focus on three cases and two historic periods: the Czech lands and France in the nineteenth century and the Republic of Ireland in the $20^{\text {th }}$ century. A further article deals with Northern Ireland and the border counties of the 
Republic. $^{4}$ There are significant parallels between these cases, but also sharp divergences. In Bohemia and France the reformation took root as an indigenous movement and made significant headway before being crushed by the counterreformation. There followed displacement, forced conversion and diaspora and the reduction of Protestant numbers to a tiny minority. In Ireland the reformation was introduced from outside as part of a process of colonialisation. The attempt to impose it on the majority failed and Protestants remained an ethnically distinct minority. But Bohemia shares with Ireland an imperial dynamic and a process of displacement and replacement of the ruling class, in Bohemia after 1628, in Ireland in a succession of plantations from the 1560 s onwards. What makes Ireland so different, however, is that the Protestant minority with external support defeated the Catholic majority and ruled over it for centuries. For Protestants in the Czech lands and in France the centuries after the reformation were ones of marginalisation and persecution; in Ireland they were ones of privilege and power.

The situation of French and Czech Protestants improved dramatically from the late $18^{\text {th }}$ century, beginning in the Hapsburg lands with the Edict of Toleration of 1781, in France with the Revolution. In both countries Protestants went on to play a role in public life disproportionate to their size in the population. The way this happened is the subject of Rigoulot's and Cabanel's articles. In France the Revolution of 1789 articulated a vision of a state founded on universal rights in which religious belief and practice were confined to the private realm; just as important it split the Catholic population down the middle. Catholic, clericalist royalists were now pitted against anti-clerical republicans. By aligning themselves politically with the latter, Protestants were able to advance their particular interest in the name of universalism. Indeed there 
was a specific moment - the early years of the Third Republic - when they had a presence in in government out of all proportion to their numbers in the population. As Rigoulot points out, this raised public profile fuelled the last great surge of French anti-Protestantism. Once it burned itself out, Protestants had secured their long sought place in the nation and the public sphere.

The geo-politics of the Czech situation were quite different. France was a leading European nation; the Czechs were a subordinated 'proto-nation' within a multinational, dynastic empire. Four centuries of Hapsburg rule meant that the ruling class was German-speaking and Czech was the dialect of the lower classes. Czechs made their language a national one, created a narrative that vindicated their claim to be one of Europe's old nations, while working for autonomy from the imperial centre which itself was caught up in a bigger battle with a unifying Germany. In the event, as the core of a new independent Czechoslovak state in 1918, their success exceeded their wildest expectations. Within this overall Czech achievement, there was, Cabanel points out, a distinctly Protestant one. In an overwhelmingly Catholic country, Protestantism had been placed at the very centre of national identity and of the state. Two contributions were crucial. One was the writing of the Protestant historian Frantisek Palacký who grounded the Czech myth of nationhood in the Hussite rebellions of the $15^{\text {th }}$ century and the Protestant rebellion against Hapsburg rule in 1618. The other, the political achievement, was that of Tomás Masaryk, first president of Czechoslovakia, who gave the Palackyan version of Czech history political and institutional form. 
Meanwhile their Irish counterparts were struggling to maintain themselves against a now emancipated and rising Catholic majority who had never accepted the legitimacy of their defeat. Protestants had two options in this situation. One was the 'Czech option': to try to lead in the re-construction of the nation and in the process secure their own place within it. While a few tried to do this (McMinn 1985), the overwhelming majority stuck with the traditional option: to align themselves with Britain, the union and the empire in the hope that Britain would defend them against the Catholic threat. Was the 'Czech option' viable? It would certainly have been more difficult than in Bohemia. Irish Protestants saw themselves as Irish, but in a different way from the Catholic Irish (Ruane and Butler, 2007). It was not simply a common national narrative that had to be created, but a common national identification. There was also the matter of Catholic material grievances, particularly in relation to land. Finally, there was geo-politics. Czech Catholics and Protestants could find common ground in opposition to a largely German-speaking ruling class and external Hapsburg rule. Irish Protestants were the ruling class, allied with and traditionally loyal to the British crown: lower class Protestants benefited from this relationship and remained loyal (and deferential) to the upper class.

The problem with the traditional option, however, was that British strategic calculations were changing. By the late $19^{\text {th }}$ century placating the increasingly nationalist Irish Catholic majority had a higher priority than protecting the privileges of the traditionally loyal Protestant minority. Even then the strategy didn't work. Demands for Home Rule led on to armed insurrection and eventually after two years of a nationalist guerrilla campaign (1919-21), the British government decided to cut its losses and cede the larger part of the island to an independent Irish government. 
Irish independence placed Southern Protestants in the position that for centuries they had struggled to avoid: becoming a minority in a Catholic-dominated state.

Two articles describe how Southern Protestants adapted to their new situation while keeping continuity with their past. Lysaght discusses the privileged stratum of the Anglo-Irish gentry and sub-gentry of the prosperous region of North Cork. This tiny minority chose to keep faith with its past, which was a past that was both British and Irish. In its British aspect, this meant maintaining its British Isles-wide upper class networks and life-style. In its Irish aspect, it meant keeping its strong local roots, its identification with Ireland and its Irish identity. Politically and culturally at odds with the new state, this minority was denied any meaningful public role. Nevertheless in doing what they could to save their great houses, they saw themselves acting as custodians of a valuable part of the Irish heritage. In an ironic twist of fate, they now find common ground with their most sharply defined historic Other: the Gaelic Irish communities of the West who are also in terminal decline.

Butler and Ruane describe a very different Protestant stratum: the small to middle sized farmers and small-town Protestants of West Cork, a group not noticeably more privileged than their Catholic neighbours. This group could not keep their distance indefinitely from the wider society, but integrating with it was a slow and for a time difficult process. They let go of their past British identification which was now a liability. But they could not let go of their distinctive sense of Irishness which differed in values, narratives and historic resonances from the Catholic Irish one. Instead two separate identity-systems and communities lived side by side, for the most part peacefully, but with boundaries carefully maintained. From the 1960s these divisions 
have been challenged and the boundaries made porous at the local level, but a strong sense of minority identification and cultural difference remains.

Todd et al describe a superficially similar Protestant population in the Southern border counties of Louth and Monaghan: while clearly asserting their Irish identity and their political distance from Northern Protestants, some are beginning to assert common cultural values with Protestants in the North which Irish society as a whole might benefit from. Protestants in Northern Ireland - demographically dense, politically assertive - renewed their power over Catholics and dependence on British backing after partition. The final ending of that power - with the Good Friday Agreement of 1998 - opens new options. A few are using the values of their religious tradition to criticise unionist dominance in the past. Some manage to privatise their religion, ridding it of ethnic and national identification, and integrating unproblematically into predominantly Catholic localities. Others again struggle to affirm their tradition without at the same time defending, or grieving, a lost dominance. In each case the changing of traditional ethno-religious identities and boundaries requires work, the seizing of new opportunities, the renegotiation of relationships, often against others' ascriptions and interactional challenges.

What can be learned from these cases? One lesson is the enduring and tenacious quality of Europe's reformation-counterreformation identities. Their form has changed over time, and their specifically religious content has been much diluted, but the continuities are striking. There has also been striking continuity in the ways in which this distinction presents itself as a religious or political 'problem': whether overtly in Ireland, or as memory in France. Part of it stems from the logic of the 
minority-majority relationship, but one can also identify more specific path-dependent dynamics (Ruane 2008). With one exception, Northern Ireland, this no longer carries with it the potential for political conflict, but the cultural legacy remains important even in the most secularised parts of Europe (Byrnes and Katzenstein 2006).

The second lesson is that 'modernisation' - whether understood as secularisation or democratisation or both - is no master variable in explaining the end of European religious conflict. It is often assumed that with modernisation comes the removal of the religious from the political arena and the weakening of its influence on relationships. Most certainly the separation of church and state played a role in the French and Czech cases. But the manner in which the Protestants minorities in these countries were integrated into the state and nation cannot be understood simply in terms of admission to full citizenship. Crucial in both cases was the specific political process by which ancien régime was turned into modern state. In each case a clericalist-anti-clericalist divide opened up within a previously homogenous Catholic population, enabling Protestants to align themselves with anti-clericalist republicans and democrats, and to create - with them - a concept of state and nation consistent with their specific values. This historic conflict was settled well in advance of any farreaching secularisation.

A third, related, issue is the role of choice, strategy and events. Pabian (forthcoming) argues that three competing versions of nationhood - liberal, Catholic and Protestant - struggled for ascendance in $19^{\text {th }}$ century Bohemia, each with different assessments of the Hussite and reformation past and its meaning for the present. What consolidated the victory of the liberals was the completely unanticipated break-up of 
the Austro-Hungarian empire. In France the dramatic challenge to the old-Catholic nation-state - the Revolution - came at the outset of the process. There followed a succession of upheavals before the republic finally emerged, close to a century later, as the definitive form of the French state. Had political institutions stabilised sooner, Protestants would have faced a very different set of opportunities and constraints and would no doubt have created a different political narrative for themselves. Could things have worked out differently in Ireland? There were certainly strong path dependent tendencies, and a structural basis to the settlement of 1921 (Ruane 2008), but the answer is assuredly yes.

This raises a final question. In both the French and Czech cases Protestants made decisive interventions at moments of rupture and by their interventions shaped the course of events. Was there a specific theologically based sensibility involved here, an example of what Walter Benjamin has described as an enlisting of 'the services of theology' for political change, an imagining of the 'messianic opening' or turning point where historical patterns could be broken (Benjamin, 1969, 253-5)? If so it raises the question of why more Irish Protestants did not respond in that way. A rational choice explanation might be given: that the balance of risks and benefits pointed in the direction of cleaving to the traditional protector and ally. But it may owe something also to the dominance within Irish Protestantism of two theological traditions: a conservative non-prophetic Anglicanism deeply attached to the status quo, and an apocalyptic evangelicalism that could not contemplate compromise with Catholics under any circumstances. 
Can any lessons be drawn from this for addressing the problems of the present, in particular the political tensions arising from the presence of new religious minorities? One conclusion is clear. The record of the past suggests that neither modernisation, democratisation nor secularisation will be enough to resolve deep-set tensions. The long-term resolutions involved a restructuring of polity and nation in a way consistent with minority, as well as majority culture. In the past, such opportunities were rare and demanded choice, strategy and political fortune. Existing and emerging pathdependent patterns of conflict are unlikely to be overcome more easily

\section{References}

Bail, C. (2008) The configuration of symbolic boundaries toward immigrants in twenty-one European countries. American Sociological Review, 73, 37-59.

Baubérot, Jean (1988). Le Protestantisme: Doit-il Mourir? Paris: Seuil.

Benjamin, W. (1969) Theses on the Philosophy of History. In Illuminations (edited and with introduction by H. Arendt). New York: Schocken.

Bowen, K. (1983). Protestants in a Catholic State; Ireland's Privileged Minority Dublin: Gill and Macmillan.

Brubaker, R. (2004) Ethnicity without Groups. Cambridge Ma: Harvard U. Press.

Byrnes, T. A. and Katzenstein, P. J. eds. (2006) Religion in an Expanding Europe.

Cambridge: Cambridge University Press.

Coakley, J. (ed.) (2003) The Territorial Management of Ethnic Conflict. London:

Frank Cass $\left(2^{\text {nd }} E d\right)$. 
Colley, L. (1992). Britons: Forging the Nation 1707-1837. New Haven: Yale University Press.

Davie, G. (2002) Europe: the Exceptional Case. Parameters of Faith in the Modern World. Darton,Longman \& Todd

Fetzer, J. and Soper, J.C. (2005) Muslims and the State in Britain, France and Germany. Cambridge: Cambridge University Press.

Flora, P. (ed.) (1999). State Formation, Nation Building and Mass Politics in Europe: The Theory of Stein Rokkan. Oxford: Oxford University Press.

Gross, Michael B. (2004). The War Against Catholicism: Liberalism and the AntiCatholic Imagination in Nineteenth-Century Germany. Michigan: University of Michigan Press.

Hastings, A. (1997). The Construction of Nationhood: Ethnicity, Religion and Nationalism. Cambridge: Cambridge University Press.

Jenkins, Philip (2007) God's Continent: Christianity, Islam and Europe's Religious Crisis. Oxford: Oxford University Press.

Kaufmann, E. P. (ed.) (2004). Rethinking Ethnicity: Majority Groups and Dominant Minorities, London: Routledge

Keating, M. (2001). Plurinational Democracy. Oxford: Oxford University Press.

Liedtke, R. and Wendehorst, S. (eds.) (1999). The Emancipation of Catholics, Jews and Protestants: Minorities and the Nation State in Nineteenth Century Europe. Manchester: Manchester University Press.

Lužný, D. and Václavík, D. (2007) Character of Czech Secularism. Tension between Institutional and Individual Religiosity in the Czech Republic. In Miklós Tomka and Edit Revay (eds) Church and Religious Life in Post-Communist Societies. Vyd. 1. 
Budapest: International Study of Religion in Eastern and Central Europe Association, pp. 67-76.

McMinn, J.R.B. (1985) Against the Tide: J. B. Armour Irish Presbyterian Minister and Home Ruler. Belfast : PRONI

Marx, A. W. (2003). Faith in Nation: Exclusionary Origins of Nationalism. Oxford: Oxford U. Press.

McLeod, Hugh. (2000). Secularisation in Western Europe, 1848 - 1914. London, Palgrave Macmillan.

Mews, S. (ed.) (1982). Religion and National Identity. Oxford : Basil Blackwell. Mitchell, C. (2006). Religion, Identity and Politics. Aldershot: Ashgate.

Pabian, Petr (forthcoming) Inventing the Hussite Nation: Liberals, Catholics, and Protestants in Conflict over Czech national Identity. In D. R. Holeton and Z. V.

Zdeněk (eds.) The Bohemian Reformation and Religious Practice, vol. 6. Prague:

Academy of Sciences of the Czech Republic.

Rokkan, S. \& Urwin D. (1983) Economy, Territory, Identity: Politics of West European Peripheries. London: Sage.

Ruane, J. (2008) Majority-minority conflicts and their resolution. Protestant minorities in France and Ireland. In J. Todd, L. Cañás Bottos and N. Rougier, eds., Political Transformations and National Identity Change. London: Routledge, 195218.

Ruane, J. \& Butler, D. (2007). Southern Irish Protestants. An example of deethnicisation? Nations and Nationalism, 13 (4), 619-636

Smith, Helmut W. (1995) German Nationalism and Religious Conflict. Princeton: Princeton University Press. 
Wimmer, A. (2008)_The making and unmaking of ethnic boundaries: a multi-level process theory. American Journal of Sociology 113 (4) 970-1022.

${ }^{1}$ Joseph Ruane acknowledges funding from the Irish Research Council for the Humanities and Social Sciences (IRCHSS) for the project 'Irish Protestants in the European Context: Commonalities and Differences between Protestants in Cork city and county (Ireland) and in the Département of the Gard (France) (2005-8), and CNRS funding for Patrick Cabanel's participation in the project. Jennifer Todd acknowledges an IRCHSS senior research fellowship 2006-7.

${ }^{2}$ It is indicative of the declining interest in religious conflict that it has needed to be argued that the Northern Ireland conflict has a religious dimension: see Ruane and Todd, 1996, pp. 22-30; Mitchell, 2006.

${ }^{3}$ On the difficulties with modernisation as a general explanation, see McLeod 2000.

${ }^{4}$ Viewed within Northern Ireland, Northern Protestants are a majority, but they are a minority on the island of Ireland as a whole, a fact that is never far from their minds. 